Indexed by

\title{
$\begin{array}{ll} & \text { THE SEISMIC RESPONSE OF STRUCTURAL } \\ \text { Scopus } & \text { OUTRIGGER SYSTEMS IN THE TALL BUILDINGS }\end{array}$
}

\section{Mohamed Husain}

Zagazig University, Structural Engineering Department, Zagazig, Egypt

\section{Hilal Hassan}

Zagazig University, Structural Engineering Department, Zagazig, Egypt

\author{
Heba A. Mohamed \\ Zagazig University, Structur- \\ al Engineering Department, \\ Zagazig, Egypt
}

Key words: lateral stiffness, reinforced concrete outrigger system, time history analysis, MIDAS-GEN

doi:10.5937/jaes0-30837

\section{Cite article:}

Husain, M., Hassan, H., Mohamed, H. A., Eigharbawy, E. S. (2021) THE SEISMIC RESPONSE OF STRUCTURAL OUTRIGGER SYSTEMS IN THE TALL BUILDINGS, Journal of Applied Engineering Science, 19(3), 570-577, DOI:10.5937/jaes0-30837 


\title{
THE SEISMIC RESPONSE OF STRUCTURAL OUTRIGGER SYSTEMS IN THE TALL BUILDINGS
}

\author{
Mohamed Husain', Hilal Hassan', Heba A. Mohamed', Eman Saeed Elgharbawy² \\ ${ }^{1}$ Zagazig University, Structural Engineering Department, Zagazig, Egypt \\ ${ }^{2}$ Higher Institute of Engineering and Technology, Structural Engineering Department, Belbeis, Egypt
}

One of the advanced structural systems that have been applied in tall buildings to improve the building strength during quake loads is the outrigger system. Most of the previous researches interested to study the behavior of steel outrigger truss system, although the hard connection between the concrete and steel members may give us the inaccurate output. For that, This research aims to find the best structural concrete outrigger system by performing a comparison between two structural outrigger systems, the wall beam outrigger system, and the vierendeel outrigger system which makes the building facing strong actual earthquakes. All the models were analyzed in the advanced Midas-Gen software program and the building response was studied under El-Centro time history earthquake load. And also, finding the best outrigger position through the building height when the outrigger is applied in one and two stories. This comparison is built on different parameters as storey drift, storey drift ratio, and the base storey overturning moment. The results showed that a one-storey wall beam structural system is better than two stories vierendeel structural system when these systems are applied as an outrigger system. The best position for one storey outrigger is about 0.45 of the total building height and for the two stories outrigger, the 0.20 and 0.45 of the total building height are the best positions. Overall, the concrete outrigger systems are an effective structural system to make the tall buildings facing the earthquake loads.

Key words: lateral stiffness, reinforced concrete outrigger system, time history analysis, MIDAS-GEN

\section{INTRODUCTION}

The development of structural systems to withstand unexpected earthquake loads is the basic important study in Egypt today. That is because of the rapid spread of new cities as the administrative capital and the City of Alamein which are characterized as monumental construction projects with high residential and touristic towers. Although Egypt is classified as a low seismic region, it had seen devastating earthquakes throughout its history. Through the last century, Egypt had seen five destructive earthquakes, which caused a collapse in the facilities and loss of lives. Especially, in October 1992, Egypt had seen a devastating earthquake that reached 5.6 Richter. Since that time, Egypt had paid attention to develop earthquake Egyptian codes for calculating earthquake Loads and also dividing Egypt into regions according to the seismic strength. For that, the chosen structural system must be able to increase the stiffness and strength of the structures to resist the earthquake loads. That increasing the challenges to develop the existing construction systems of the tall buildings to be suitable for many conditions, such as seismically, soil characteristics, and quake loads intensity, [1].

The tall buildings resist the earthquake loads as a cantilever action because the inner core and perimeter frame are uncoupled. The outrigger is an earthquake resisting system that is tied the perimeter columns to the inside core walls to behave as one system in resisting the earthquake loads [2]. The structural outrigger system improves the sidelong stiffness of the tall buildings and increases their resistance during earthquakes. When the earthquake loads affect the structure, the perimeter columns reduce the moment on the core by the outriggers through tension in the facing earthquake columns and compressed the opposite columns, [3]. The loads transferring from the core to exterior columns by two method techniques or in other meaning, there are two types of outrigger system according to load transfer which these are Conventional and Virtual systems [4], [5]. The Conventional system type means that the earthquake moment transfers from internal core walls to the external building columns directly by the stiff outrigger arms. But the virtual system type depends on double inflexible floor diaphragms to transfer the earthquake moment from the core to external building columns, [6]. The earthquake moment transferred as a couple of horizontal moments from the core to the double inflexible floors and converted by the outrigger to vertical forces at the border columns. The outrigger system could be applied in one or double and triple stories through the tallness of the structure. The outrigger system differs also in the material which could be steel or reinforced concrete [7], [8], [9].

Most of the previous researches had interested to find the best position of the outrigger system in the tall building when applying them as steel bracing $[\mathrm{V}$ and $\mathrm{X}]$ sections and as a concrete deep beam under the elastic limit of static and dynamic loads. The authors in [10] interested to study the theory of the outrigger to decrease the drift and improve the sidelong stiffness of tall buildings under 
the quake loads effect. This theory was built on a deep beam connected between the internal core and exterior columns to make the wall and columns worked together by generating a tension force in the facing earthquake columns and compression in the opposite columns. They hadn't studied only the behavior of the outrigger system, but also finding the best location of one storey outrigger system and the other with two stories outrigger system. For that, 3D models with different positions of outrigger were analyzed in the ETAB program under dynamic and static lateral loads to study the response of all models in the $X$ and $Y$ direction. All the results were plotted on graphs between the studied parameters and the floor number. They found that the best position of one storey outrigger level is about $0.47 \mathrm{H}$ and about $0.333 \mathrm{H}$ and $0.667 \mathrm{H}$ are the best positions when used two stories outrigger system, [2]. In [11] the authors interested to increase the stiffness of RC slender tall buildings to resist lateral loads. For that, they studied four different heights of buildings $30,40,50$, and 60 with the central core under lateral loads to identify their stiffness and fundamental period time. One storey and two stories outrigger truss system which connected between the central core and external columns had been used to improve the stiffness. They also changed the outrigger position through the height of all models. All models were analyzed in an ETAB program under wind loads and linear static and dynamic earthquake loads besides permanent loads according to the Indian standard code. After the analysis, they concluded that the $1 / 3 \mathrm{rd}$ distance is the optimum position of one outrigger in the slender tall buildings. The $1 / 3$ rd distance from the top and bottom are the optimum positions of two stories outrigger in the slender tall buildings. And also, the authors in [12] Studied the deflection control and frequency optimization of one, two, and three stories of truss outrigger system in 28,42 , and 57 storey buildings under lateral worst wind loads. All the models had the same layout (L-shape) and the column sizes had been changed through the stories. All models were analyzed using the STRAND-7 software. The results showed that the stiffness of the building decreased when the height increased for the same plan. The outrigger system is a good solution to increase the lateral stiffness of the buildings and chive the required capacity to resist the lateral loads.

This research focused on performing a comparison between different concrete outrigger structural systems to find the suitable concrete system which makes the demand requirements close up or equal to the allowable requirements under actual strong earthquake by using advanced software program as the Midas-Gen program.

\section{Modeling layout}

3D 40-storey reference tall reinforced concrete model was considered with $9 \mathrm{mx} 9 \mathrm{~m}$ central core walls. The model is $45 \times 45 \mathrm{~m}$ with columns spaced at $9 \mathrm{~m}$ from center to center. The storey height is $3.00 \mathrm{~m}$ giving a total height of $120 \mathrm{~m}$ and all the stories are typical. The beams, com- posite columns, internal core walls, and outriggers are assumed as reinforced concrete members. The material properties and the section sizes are shown in table [1, 2]. Four groups of the models with various outrigger positions were analyzed using Midas-Gen software under the same loads.

I. The first group included four models with one storey vierendeel outrigger system which was fixed in different positions through the height, which are $0.2 \mathrm{H}$, $0.45 \mathrm{H}, 0.75 \mathrm{H}$, and $\mathrm{H}$. figure [1b]

II. The second group included four models with one storey wall beam outrigger system which was fixed in different positions through the height, which are $0.2 \mathrm{H}, 0.45 \mathrm{H}, 0.75 \mathrm{H}$, and $\mathrm{H}$. figure [1a]

III. The third group included three models with two stories vierendeel outrigger system which are

1. Model with outrigger system fixed at $0.2 \mathrm{H}$ and $0.45 \mathrm{H}$.

2. Model with outrigger system fixed at $0.2 \mathrm{H}$ and $0.75 \mathrm{H}$.

3. Model with outrigger system fixed at $0.45 \mathrm{H}$ and $0.75 \mathrm{H}$.

IV. The last group included three models with two stories vierendeel outrigger system one of them was fixed at the roof floor and the other varied in different positions through the height which are $0.2 \mathrm{H}, 0.45 \mathrm{H}$, and $0.75 \mathrm{H}$.

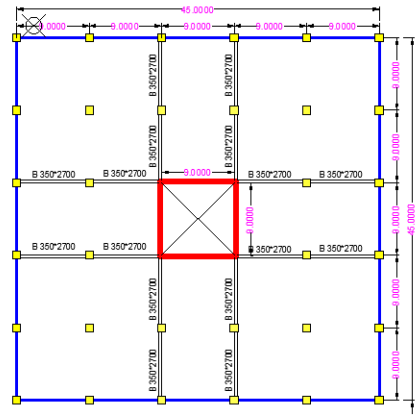

(a)

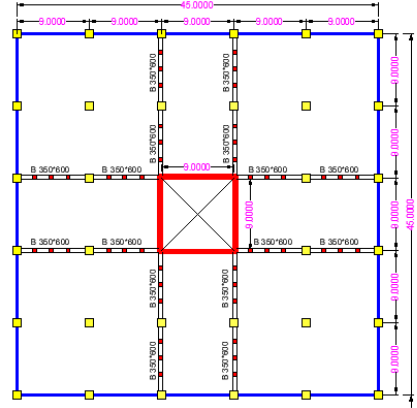

(b)

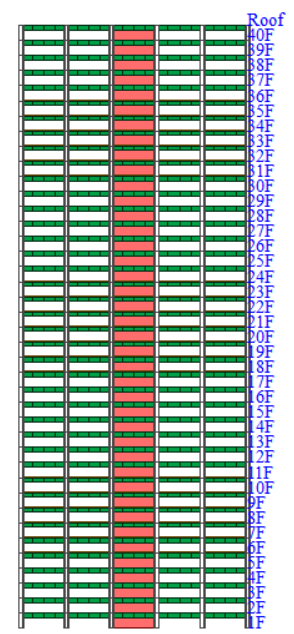

(c)

Figure 1: (a) Plan of outrigger (wall beam system), (b) Plan of outrigger (vierendeel system), (c) Building Elevation with central core portion 


\section{Methodology}

1. Create the mathematical model in the Midas-Gen software program.

2. Assign the permanent and the El-Centro time history earthquake load.

3. Performing the analysis.

4. Finding out the inferred parameters of the reference model as roof storey drifts, storey drift ratio, and base storey overturning moment

5. Analyze the models with various outrigger systems and positions.

6. Finding out the inferred parameters of the models with various outrigger positions as roof storey drifts, storey drift ratio, and base storey overturning moment

7. Make a comparison between the reference model parameters and the models with a different arrangement of outrigger parameters by plotting all results in graphs.

Table 1: Sections size $(\mathrm{mm})$ used for the numerical model

\begin{tabular}{|c|c|c|}
\hline \multicolumn{2}{|c|}{ Composite column } & $1000 \times 1000$ \\
\hline \multicolumn{2}{|c|}{ Shear wall thickness } & 350 \\
\hline \multicolumn{2}{|c|}{ Flat slab thickness } & 250 \\
\hline \multicolumn{2}{|c|}{ Marginal beams } & $300 \times 900$ \\
\hline \multirow{3}{*}{$\begin{array}{l}\text { Outrigger di- } \\
\text { mensions }\end{array}$} & \multirow{2}{*}{$\begin{array}{c}\text { Vierendeel } \\
\text { system }\end{array}$} & Beam $350 \times 600$ \\
\hline & & COL $350 \times 600$ \\
\hline & $\begin{array}{c}\text { Wall beams } \\
\text { system }\end{array}$ & $350 \times 2700$ \\
\hline
\end{tabular}

Table 2: The material section properties

\begin{tabular}{|c|c|c|c|}
\hline Property & Concrete & Mild steel & $\begin{array}{c}\text { Compos } \\
\text { ite }\end{array}$ \\
\hline $\begin{array}{l}\text { Modulus of } \\
\text { elasticity, E } \\
\text { (MPa) }\end{array}$ & 23,503 & 200,000 & 200,000 \\
\hline $\begin{array}{c}\text { Poison's ratio, } \\
\mathbf{v}\end{array}$ & 0.200 & 0.303 & .303 \\
\hline $\begin{array}{c}\text { Mass density } \\
\left(\mathrm{kg} / \mathrm{m}^{3}\right)\end{array}$ & 2400 & 7860 & 7860 \\
\hline Strength (MPa) & $f_{c}=35$ & $\mathrm{f}_{\mathrm{v}}=400$ & $f_{p v}=360$ \\
\hline Strain & $\varepsilon c u=0.003$ & $\varepsilon y=0.00207$ & $\varepsilon y=0.002$ \\
\hline
\end{tabular}

\section{Loading}

The seismic building response was studied under time history 1940 El-Centro earthquake with $0.356 \mathrm{~g}$ peak ground acceleration. And also the permanent loads which comprise the self-building weight and the live loads $2.5 \mathrm{kN} / \mathrm{m}^{2}$ were assigned as a surface load at each storey level.

\section{Midas-Gen analysis program}

Midas-Gen is a limited component program able to perform a primary investigation of three-dimensional concrete, steel, composite, regular, and irregular structures. Midas-Gen likewise uses an assorted scope of forte limited component examination works just as present-day hypotheses of the underlying investigation deliver precise and common sense outcomes. [13]

\section{Verification}

Verification of the models is obtained through comparing the results of experimental work with the results of the same model after analyzing it by (Midas-Gen) finite element software program to check the validity of the program for simulating the RC frames seismic behavior correctly. The experimental work was performed as shown in [14]. To get the pushover curve of a $1 / 4$ size RC frame model without an infill wall. The frame is $1200 \mathrm{~mm}$ in height, measured from the column base to the top of the beam, and the span length between center lines of the columns is $1260 \mathrm{~mm}$, figure [2a]. The frame is fixed on a steel base plate and the loading was started by using a servo-hydraulic actuator. They started the loading at a very slow rate to fade the material strain rate effects. The loading responses [the pushover capacity curve] were measured by LVDTs arrangements, as shown in figure [2b], [14]. A model with the same details, as shown in fig [2a] is drawn and assigned in the Midas-Gen program. The model was tested under the nonlinear static pushover analysis method according to FEMA 356. The load combination was assigned automatically according to the Indian standard code [IS]. After the analysis, the pushover capacity curves experimentally and analytically were plotted in graph [2c] and texted in table [3] Which constitutes the incremental relationship between the base shear force and the displacement. The graph showed the difference between the pushover curve from the nonlinear finite element program (Midas-Gen) model and the pushover curve of the experimental model. The comparison between the values in table 3 and in graph [2c] showed that the two curves are so close and the max difference between them is in the range $10 \%$ approximately. This confirms that the Midas-Gen program is very accurate and possesses a high simulation of real results.

Table 3: Comparison between pushover capacity curves experimentally and analytically

\begin{tabular}{|c|c|c|c|}
\hline $\begin{array}{c}\text { Base shear } \\
\text { force [KN] }\end{array}$ & $\begin{array}{c}\text { Experimen- } \\
\text { tal displace- } \\
\text { ment [mm] }\end{array}$ & $\begin{array}{c}\text { Analytical } \\
\text { displace- } \\
\text { ment [mm] }\end{array}$ & $\begin{array}{c}\text { percentage } \\
\text { [\%] }\end{array}$ \\
\hline 0 & 0 & 0 & $0 \%$ \\
\hline 8 & 8.6 & 7.78 & $9.53 \%$ \\
\hline 16 & 10.4 & 9.59 & $7.79 \%$ \\
\hline 24 & 11.3 & 11.13 & $1.5 \%$ \\
\hline
\end{tabular}




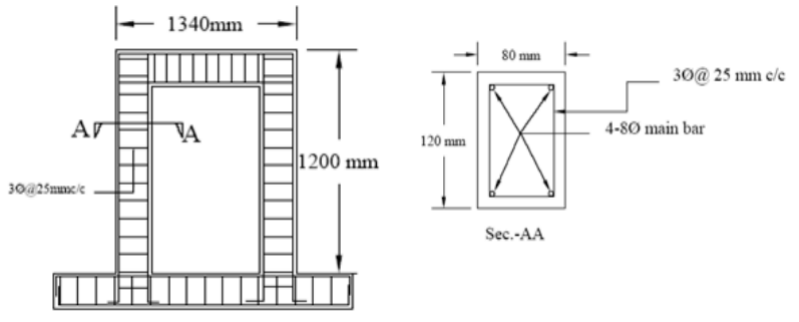

(a)

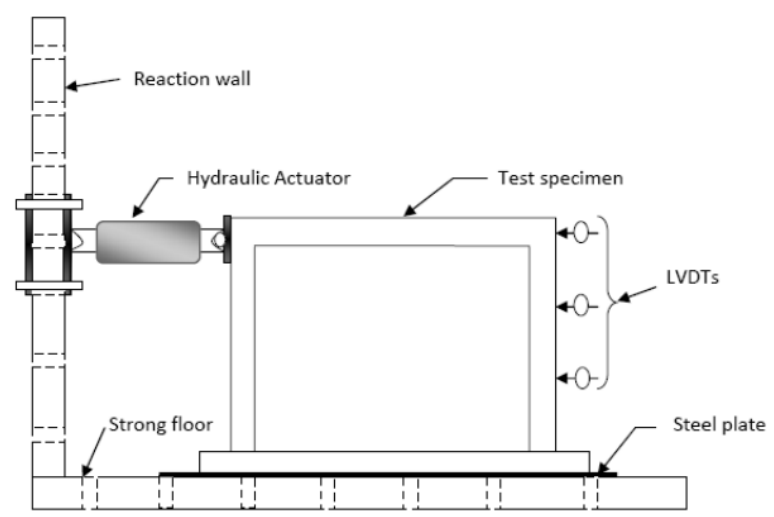

(b)

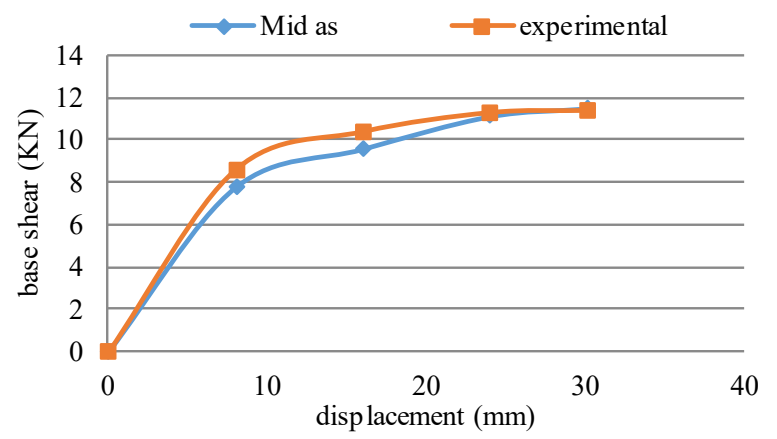

(c)

Figure 2: [a] Experimental frame model reinforcement details. [b] Experimental frame pushover loading setup, [14]. [c] Comparison between push over capacity curves experimentally and analytically

\section{RESULT AND DISCUSSION}

The results which are obtained from the analysis are compared and discussed as follows.

\section{The building natural period}

There is a relation connected between the building's natural period $\left[T_{n}\right]$, the building mode shape, and the building stiffness [K].

The natural period is the time in seconds when the building, completing one cycle of vibration under El-Centro earthquake load. The mode shape is building deformation, which occurs through the natural period under the earthquake load. The building stiffness $[\mathrm{K}]$ is the deformation building resistance that occurs under lateral loads. The natural period $\left[T_{n}\right]$, building drift [ $\left.\delta\right]$, and the building stiffness $[\mathrm{K}]$ are related by.
According to equation [1], the building stiffness $[\mathrm{K}]$ is inversely proportional to The natural period $\left[T_{n}\right]$, which

$T_{n}=2 \pi \sqrt{\frac{m}{K}}$

$K=\frac{F}{\delta}$

means a decrease in the natural period is offset by an increase in the building stiffness. And according to the equation [2], the building stiffness is inversely proportional to the building lateral drift [ $\delta]$ which means an increase in building stiffness is offset by a decrease in the lateral building drift, [15].

After the analysis, the building under the El-Centro earthquake load had an infinite number of natural periods so that it had an infinite number of mode shapes. We considered that the first mode shape is the first building deformation, which is occurring through the first natural period. After the analysis, the results show that the natural period of models with outrigger systems is lower than the natural period of the reference model in the first mode shape, as shown in table 4 . So it means that the building stiffness, increasing when adding the outrigger system to the reference model which results in a decrease in lateral building drift.

Table 4: The fundamental periods of the first mode shape

\begin{tabular}{|c|c|c|}
\hline & & mode 1 \\
\hline & Reference model & $5.98 \mathrm{sec}$ \\
\hline \multirow{2}{*}{$\begin{array}{c}\text { One storey vier- } \\
\text { endeel outrigger } \\
\text { system at differ- }\end{array}$} & OUT @ 0.2H & $5.82 \mathrm{sec}$ \\
\cline { 2 - 3 } \begin{tabular}{c} 
ent positions \\
\cline { 2 - 3 }
\end{tabular} & OUT @ 0.45H & $5.71 \mathrm{sec}$ \\
\cline { 2 - 3 } & OUT @ 0.75H & $5.833 \mathrm{sec}$ \\
\hline
\end{tabular}

\begin{tabular}{|c|c|c|}
\hline & & mode 1 \\
\hline & Reference model & $5.98 \mathrm{sec}$ \\
\hline Two stories vier- & OUT @ $0.2 \mathrm{H}$ and.45H & 5.568 \\
\cline { 2 - 3 } $\begin{array}{c}\text { endeel outrigger } \\
\text { system at differ- } \\
\text { ent positions }\end{array}$ & OUT @ $0.2 \mathrm{H}$ and.75H & 5.675 \\
\cline { 2 - 3 } & OUT @ $0.45 \mathrm{H}$ and .75H & 5.583 \\
\hline
\end{tabular}

\begin{tabular}{|c|c|c|}
\hline & & mode 1 \\
\hline & Reference model & $5.98 \mathrm{sec}$ \\
\hline Two stories vier- & OUT @ $0.2 \mathrm{H}$ and roof & 5.774 \\
\cline { 2 - 3 } $\begin{array}{c}\text { endeel outrigger } \\
\text { system at differ- } \\
\text { ent positions }\end{array}$ & OUT @ $0.45 \mathrm{H}$ and roof & 5.672 \\
\cline { 2 - 3 } & OUT @ $0.75 \mathrm{H}$ and roof & 5.806 \\
\hline
\end{tabular}

\begin{tabular}{|c|c|c|}
\hline & & mode 1 \\
\hline & Reference model & $5.98 \mathrm{sec}$ \\
\hline \multirow{2}{*}{$\begin{array}{c}\text { One storey wall } \\
\text { beam outrigger } \\
\text { system at differ- } \\
\text { ent positions }\end{array}$} & OUT @ 0.2H & $5.62 \mathrm{sec}$ \\
\cline { 2 - 3 } & OUT @ $0.45 \mathrm{H}$ & $5.42 \mathrm{sec}$ \\
\cline { 2 - 3 } & OUT @ $0.75 \mathrm{H}$ & $5.69 \mathrm{sec}$ \\
\hline
\end{tabular}




\section{Roof storey drift}

The allowable roof drift in the tall building is calculated as $[\mathrm{H} / 500]$ where $\mathrm{H}$ is the total building height. In figure [3a], the reference actual roof storey drift is $688.85 \mathrm{~mm}$ but the allowable roof drift is $240 \mathrm{~mm}$ which makes the building filed under the assigned loads. When providing a one-storey vierendeel outrigger structural system at $0.2 \mathrm{H}, 0.45 \mathrm{H}, 0.75 \mathrm{H}$, and $\mathrm{H}$ respectively the roof storey drift reduced to $605 \mathrm{~mm}, 531.2 \mathrm{~mm}, 602.5 \mathrm{~mm}$, and $645 \mathrm{~mm}$. Figure [3b] shows the reduction in reference roof storey drift from 688.85 to 432,513 , and 437.3 when providing two stories vierendeel outrigger structural system at $(0.2 \mathrm{H} \& 0.45 \mathrm{H}),(0.2 \mathrm{H} \& 0.75 \mathrm{H})$, and $(0.75 \mathrm{H}$ \& $0.45 \mathrm{H})$.

Figure [3c] shows the reduction in reference roof storey drift from 688.85 to $559.2,495.4$, and 571 when providing two stories vierendeel outrigger structural system one of them fixed at the roof and the other at $0.2 \mathrm{H}, 0.45 \mathrm{H}$, and $0.75 \mathrm{H}$. Figure [3d] shows the reduction in reference roof storey drift from $688.85 \mathrm{~mm}$ to $478.75 \mathrm{~mm}, 370.79 \mathrm{~mm}$, $503.33 \mathrm{~mm}$, and $628.37 \mathrm{~mm}$ when providing one-storey wall beam outrigger structural system at $0.2 \mathrm{H}, 0.45 \mathrm{H}$, $0.75 \mathrm{H}$, and $\mathrm{H}$ respectively. The reduction in story drift after using various outrigger systems means increasing the building stiffness, which is an expected result of the decrease in the natural period, as shown in the previous text. As shown in figure 4, the max reduction occurred at $0.45 \mathrm{H}$ for one storey outrigger system and $0.2 \mathrm{H} \& 0.45 \mathrm{H}$ are the best positions for two stories outrigger system.

\section{Storey drift ratio}

The storey drift ratio is calculated by dividing the difference between double stories displacement by the storey height. Figure 4 shows that the storey drift ratio improved in all stories when comparing it with the reference model. We observed that the max enhancement occurred at the outrigger storey by percentages $20 \%, 29.2 \%, 22.58$, and $26 \%$ when providing one-storey vierendeel outrigger structural system at $0.2 \mathrm{H}, 0.45 \mathrm{H}, 0.75 \mathrm{H}$, and $\mathrm{H}$ respectively, as shown in figure [4a]. Figure [4b] shows that the storey drift ratio improved by percentages $33.87 \%$, $33.8 \%$, and $29.09 \%$ when providing two stories vierendeel outrigger structural system at $(0.45 \& 0.75 \mathrm{H})$, $(0.45 \mathrm{H} \& 0.2 \mathrm{H})$, and $(0.2 \mathrm{H} \& 0.75 \mathrm{H})$, and Figure [4c] shows that the storey drift ratio improved by percentages $32 \%$, $23 \%$, and $20 \%$ when providing two stories vierendeel outrigger structural system one of them fixed at the roof and the other at $0.45 \mathrm{H}, 0.75 \mathrm{H}$, and $0.2 \mathrm{H}$. Figure [4d] shows that the storey drift ratio improved by percentages $44 \%$, $39.7 \%, 36 \%$, and 35.2 when providing one-storey wall beam outrigger structural system at $0.2 \mathrm{H}, 0.45 \mathrm{H}, 0.75 \mathrm{H}$, and $\mathrm{H}$ respectively. The results show the storey drift ratio decreased near the outrigger storey when the outrigger location changed through the height. The max improvement in one storey outrigger drift ratio when comparing it with the reference model storey drift ratio is at $0.45 \mathrm{H}$. And the max improvement in the storey drift ratio when apply- ing two outriggers, one of them must fix at $0.45 \mathrm{H}$ and the other between $0.75 \mathrm{H}$ and $0.2 \mathrm{H}$. When the outrigger was fixed at the roof the other best position at $0.45 \mathrm{H}$ as well.
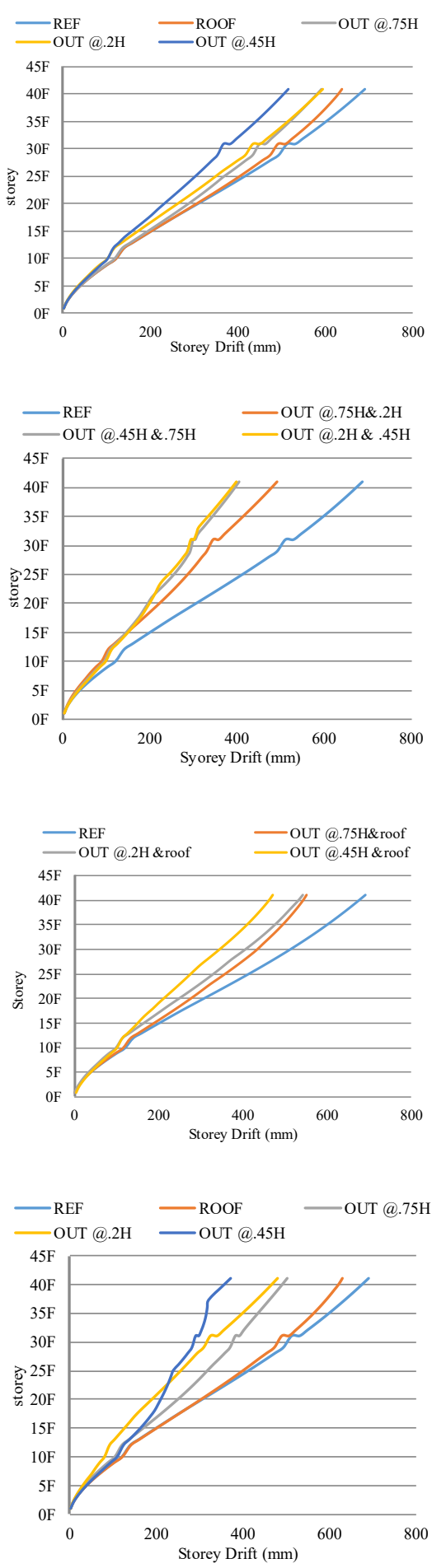

Figure 3: Variation of storey drifts between the reference model and different locations of [a] one-storey vierendeel outrigger structural system models [b] two stories outrigger vierendeel structural system models [c] two stories vierendeel outrigger structural system models with one of them fixed at the roof floor [d] one-storey wall beam outrigger structural system models 


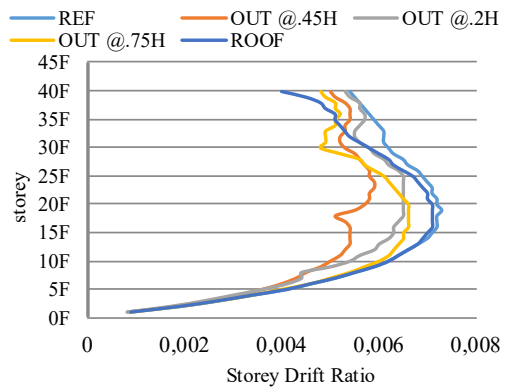

(a)

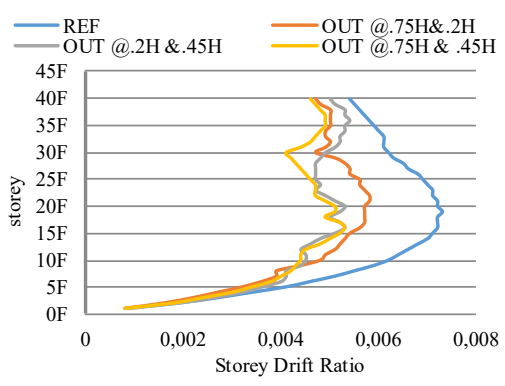

(b)

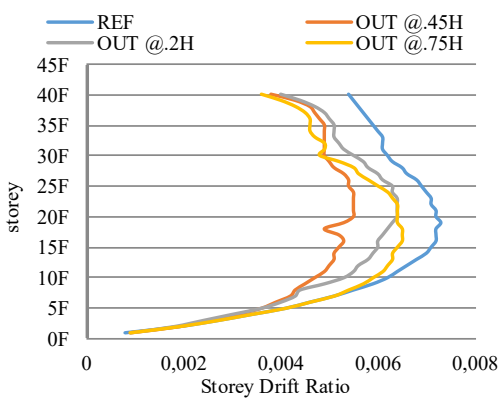

(c)

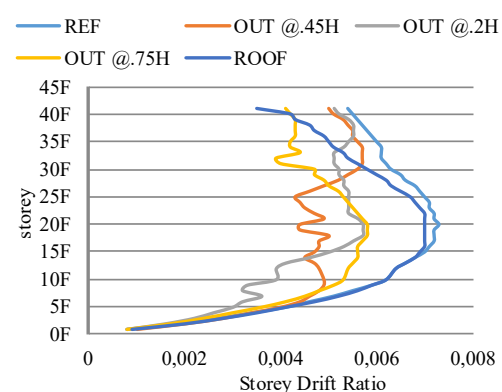

(d)

Figure 4: Variation of the storey drift ratio between the reference model and different locations of [a] one storey vierendeel outrigger structural system [b] two stories vierendeel outrigger structural system [c] two stories vierendeel outrigger structural system with one fixed at the roof floor. [d] one-storey wall beam outrigger structural system

\section{The overturning moment at the base storey}

The base storey overturning moment because of the El-Centro earthquake is an overall improvement when the outrigger is added to the model. Because the outrigger helps to reduce the core moment and involving perimeter column axial forces that are helping to resist overturning from the lateral load. The outrigger system is helping to reduce mat shear demand, flexural demand, and net uplift conditions by spreading loads from overturning across the tower footprint.

All the base stories overturning moment were texted in table 5 and plotted in figure 5. Figure [5a] and table [5] show that the base storey overturning moment reduced by percentages $9.79 \%$, $17.39 \%, 7.21 \%$, and $1.4 \%$ when providing one-storey vierendeel outrigger structural system at $0.2 \mathrm{H}, 0.45 \mathrm{H}, 0.75 \mathrm{H}$, and $\mathrm{H}$ respectively. In Figure [5b] and table [5], the base storey overturning moment reduced by percentages $31.29 \%, 20.52 \%$, and $27.61 \%$ when providing two stories vierendeel outrigger structural system at $(0.2 \mathrm{H} \& 0.45 \mathrm{H}),(0.2 \mathrm{H} \& 0.75 \mathrm{H})$, and $(0.75 \mathrm{H} \& 0.45 \mathrm{H})$. In Figure [5c] and table [5], the base storey overturning moment reduced by percentages $12.66 \%, 20.92 \%$, and $7.65 \%$ when providing two stories vierendeel outrigger structural system, one of them fixed at the roof and the other at $0.2 \mathrm{H}, 0.45 \mathrm{H}$, and $0.75 \mathrm{H}$. In Figure [5d] and table [5], the base storey overturning moment reduced by percentages $27.76 \%, 31.51 \%, 18.16 \%$, and $2.16 \%$ when providing a one-storey wall beam outrigger structural system at $0.2 \mathrm{H}, 0.45 \mathrm{H}, 0.75 \mathrm{H}$, and $\mathrm{H}$ respectively.
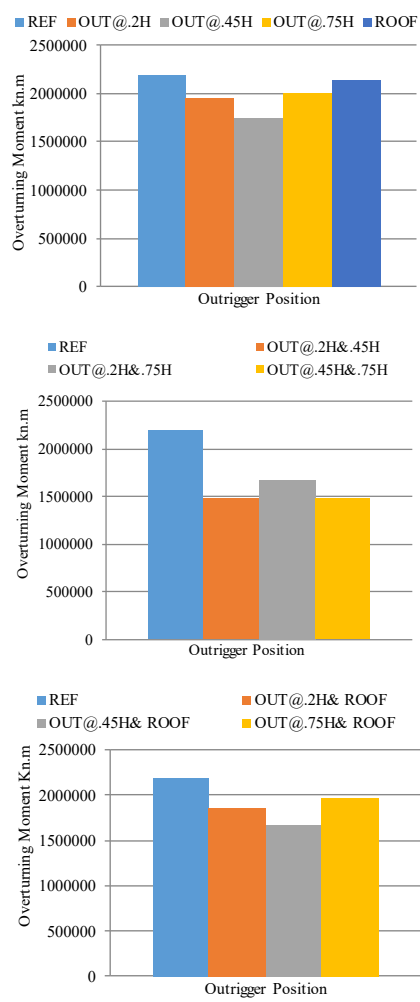

(a)

(b)

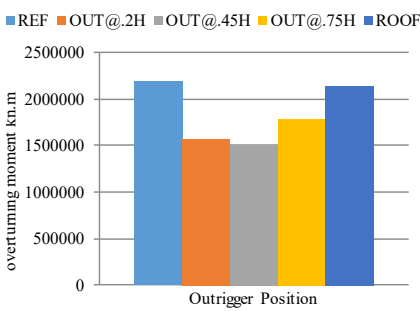

(c)

Figure 5: Variation of base storey overturning moment between the reference model and different locations of [a] one-storey vierendeel outrigger structural system [b] two stories vierendeel outrigger structural system [c] two stories vierendeel outrigger with one of them fixed at the roof floor [d] one-storey wall beam outrigger structural system 
Table 5: Comparison between base storey overturning moment in [KN] for different positions of vierendeel and wall beam outrigger structural systems in one and two stories

\begin{tabular}{|c|c|c|c|c|c|}
\hline \multicolumn{6}{|c|}{ Positions of single vierendeel outrigger system } \\
\hline \multirow{2}{*}{ Mom [KN] } & ref & $0.2 \mathrm{H}$ & $0.45 \mathrm{H}$ & $0.75 \mathrm{H}$ & roof \\
\hline & 2186920 & 1972860 & 1806580 & 2029150 & 2156400 \\
\hline \multicolumn{6}{|c|}{ The positions of two stories vierendeel outrigger system } \\
\hline \multirow{2}{*}{ Mom [KN] } & ref & $0.2 \mathrm{H} \& 0.45 \mathrm{H}$ & $0.2 \mathrm{H} \& 0.75 \mathrm{H}$ & $0.45 \mathrm{H} \& 0.75 \mathrm{H}$ & \\
\hline & 2186920 & 1502680 & 1738060 & 1583030 & \\
\hline \multicolumn{6}{|c|}{ The positions of two stories vierendeel outrigger system } \\
\hline \multirow{2}{*}{ Mom [KN] } & ref & $0.2 \mathrm{H} \&$ roof & $0.45 \mathrm{H} \&$ roof & $0.75 \mathrm{H} \&$ roof & \\
\hline & 2186920 & 1909950 & 1729390 & 2019600 & \\
\hline \multicolumn{6}{|c|}{ Positions of single wall beam outrigger system } \\
\hline \multirow{2}{*}{ Mom [KN] } & ref & $0.2 \mathrm{H}$ & $0.45 \mathrm{H}$ & $0.75 \mathrm{H}$ & roof \\
\hline & 2186920 & 1579810 & 1497770 & 1789670 & 2139560 \\
\hline
\end{tabular}

\section{CONCLUSIONS}

1. This research studied the adequacy of the outrigger system to increase building strength through earthquakes. So that, the outrigger was added to the 40 -storey building as a vierendeel structural system and also as a wall beam structural system. The position of the outrigger differed through the height and was applied in one-storey and two stories. The seismic response was studied under the El-Centro earthquake and the comparison between the models depended on many parameters as the roof storey drift, the storey drift ratio, and the base storey overturning moment. After the analysis, the conclusions could be drawn depending on the above outcomes:

2. The best situation of one-storey outrigger at $0.45 \mathrm{H}$ because it is observed that, the roof storey drift reduced by $22.8 \%$, and $46.2 \%$ when the outrigger was added to the reference model as a vierendeel structural system and a wall beam structural system, respectively. The storey drift ratio improved by percentages $29.2 \%$ and $39.72 \%$ for models with a vierendeel structural system and a wall beam structural system, respectively. Improvement in the base storey overturning moment resulting up to $17.39 \%$ and $31.51 \%$ reduction at the moment by using outrigger as a vierendeel structural system and wall beam structural system, respectively.

3. The best situation of two stories outrigger at $(0.2 \mathrm{H} \& 0.45 \mathrm{H})$ because it is observed an improvement in a roof storey drift, storey drift ratio, and the base storey overturning moment resulting up to $37.3 \%$, $33.8 \%$, and $31.29 \%$ reduction respectively, compared with the model without the outrigger system.

1. The wall beam outrigger system is better than two stories vierendeel outrigger system and makes the building demand results close up from the allowable value requirements.
2. Increasing the number of outrigger stories, and their dimensions also helping to get closer to the allowable value requirements.

3. Overall, the outrigger is an efficient approach to expand the stiffness and the strength of the tall structure under quake loads.

\section{REFERENCES}

1. Mistry, K. Z., Dhyani, D. J. (2015). Optimum Outrigger Location in Outrigger Structural System for High Rise Building. International Journal of Advance Engineering and Research Development, 2 (05). DOI: 10.21090/ijaerd. 020536.

2. Kamath, K., (2012). A Study on Static and Dynamic Behavior of Outrigger Structural System for Tall Buildings. Bonfring International Journal of Industrial Engineering and Management Science, 2 (4), pp. 15-20. DOI: 10.9756/bijiems. 1655.

3. Kim, H.-S., Lim, Y.-J., \& Lee, H.-L. (2020). Optimum location of outrigger in tall buildings using finite element analysis and gradient-based optimization method. Journal of Building Engineering, 31, p.101379. DOI: 10.1016/j.jobe.2020.101379

4. Rathore, A., Maru, S. (2017). Dynamic Analysis of outrigger structural system in tall building. International Journal of Modern Trends in Engineering \& Research, 4 (12), pp. 199-208. DOI: 10.21884/ijmter. 2017. 4403. jzekk.

5. Choi, H. S., Ho, G., Joseph, L., \& Mathias, N. (2017). Introduction to Outrigger Systems. Outrigger Design for High-Rise Buildings, pp. 13-24. DOI: 10.1201/9781315661971-7.

6. Khandelwal, R., Singh, S. (2020). Optimum Shape and Position of Outrigger System for High Rise Building under Earthquake Loading. Regular Issue, 9(3), pp.3268-3275. DOI:10.35940/ijitee.c8961.019320 
7. Gawate, Alpana L., \& J. P. Bhusari. (2015). "Behavior of Outrigger Structural System for High-rise Building." International Journal of Modern Trends in Engineering and Research, e-ISSN 2349-9745.

8. Taranath, B.S., (2009). Reinforced Concrete Design of Tall Buildings), pp. 685-792. DOI:10.1201/9781439804810-c8.

9. Ragite, N.C., (2019). Outrigger Structural System in High Rise Building to Control Deflection: A Review. International Journal for Research in Applied Science and Engineering Technology, 7(4), pp.3490-3493. DOI: 10.22214/ijraset.2019.4587.

10. Herath, N., et al. (2009). Behaviour of outrigger beams in high rise buildings under earthquake loads. Australian Earthquake Engineering Society Conference, Australia.

11. Ahmed, J., Sreevalli, Y. (2014). Application of Outrigger in Slender High Rise Buildings to Reduce Fundamental Time Period. 6th IRF International Conference, Chennai, India, July.
12. Tabassum, F., Fawzia, S., \& Nasir, A. (2011). Study of the effectiveness of outrigger system for high-rise composite buildings for cyclonic region. International Conference on Electrical, Computer, Electronics and Communication Engineering, Australia.

13. Midas, I. T. "Midas Gen on-line manual: general structure design system." MIDAS Information Technology. Available at: http://manual.midasuser.com/ EN_Common/Gen/855/index.htm

14. Paul, G., Agarwal, P. (2012). Experimental verification of seismic evaluation of RC frame building designed as per previous IS codes before and after retrofitting by using steel bracing. Asian Journal of Civil Engineering (building and housing), 13 (2), PP. 165-79.

15. Murty, C. V. R., et al. (2012). Some concepts in earthquake behaviour of buildings. Gujarat State Disaster Management Authority, Government of Gujarat. 